\title{
Diamond on quadriceps
}

\section{A frequent sign in dysferlinopathy}

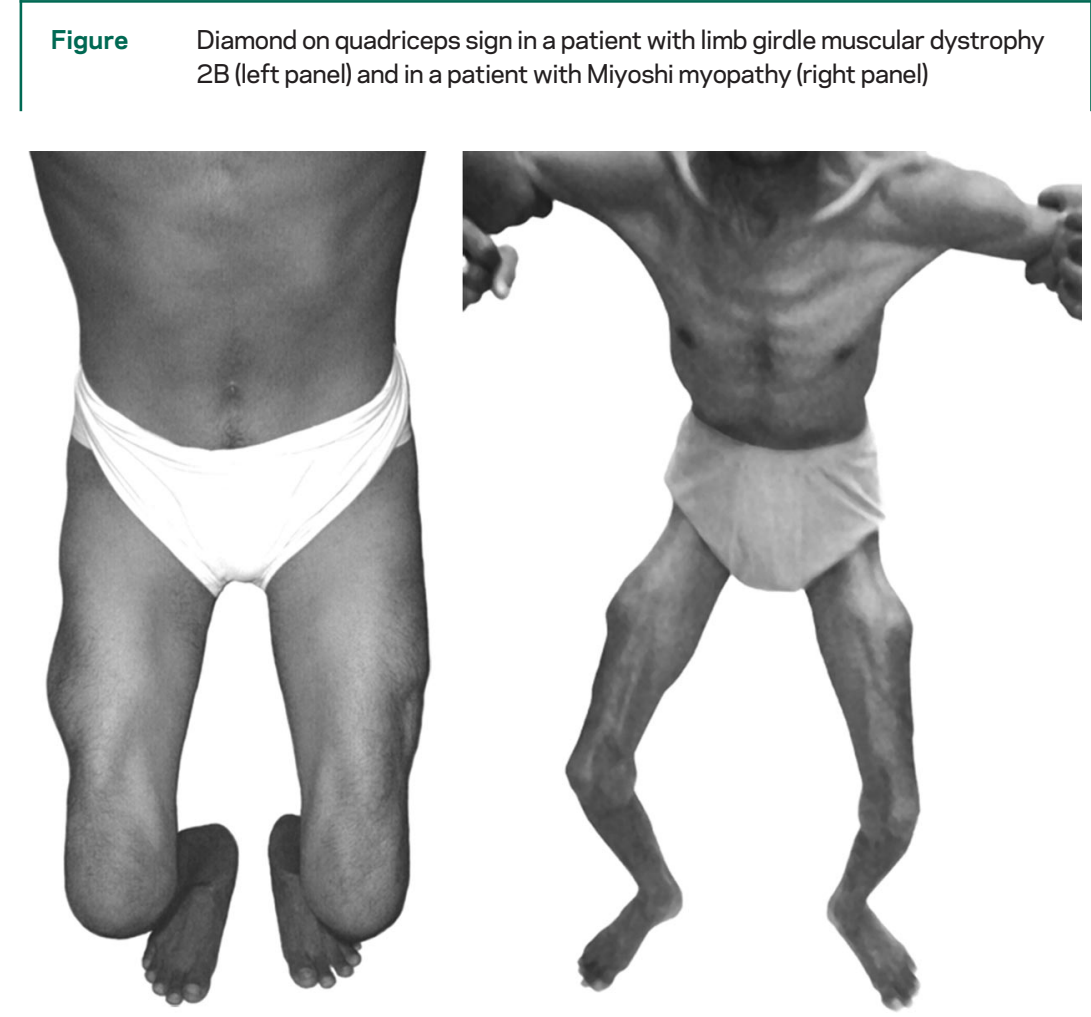

Note that some weak patients required partial support to maintain the required posture.

Patients with dysferlinopathy (11 limb girdle muscular dystrophy [LGMD]-2B and 16 Miyoshi myopathy) were asked to stand with knees slightly bent so that the quadriceps muscles were in moderate action. The anterolateral aspect of thighs was observed for any abnormal bulge. Nineteen patients $(7$ LGMD-2B and 12 Miyoshi myopathy) showed asymmetric diamond shaped bulges with wasting of muscles above and below (figure). The sign was not apparent in standing or sitting position.

Diamond on quadriceps sign indicates selectivity of dystrophic process not only among different muscles but also within a muscle as suggested earlier. ${ }^{1}$ The sign was absent in other muscular dystrophies, suggesting specificity for dysferlinopathy. It would add to the calf-head sign described earlier in Miyoshi myopathy. ${ }^{2}$

Sunil Pradhan, MD, DM, Lucknow, India

Disclosure: The author reports no conflicts of interest.

Address correspondence and reprint requests to Prof. S. Pradhan, Department of Neurology, Sanjay Gandhi Post Graduate Institute of Medical Sciences, Raebareli Road, Lucknow226 014, India; drspradhan@rediffmail.com

1. Pradhan S, Mittal B. Infraspinatus muscle hypertrophy and axillary folds wasting as the important signs in Duchenne muscular dystrophy. Clin Neurol Neurosurg 1995;91:134-138.

2. Pradhan S. Calf-head sign in Miyoshi myopathy. Arch Neurol 2006;63:1414-1417. 


\section{Neurology}

\section{Diamond on quadriceps: A frequent sign in dysferlinopathy \\ Sunil Pradhan \\ Neurology 2008;70;322 \\ DOI 10.1212/01.wnl.0000298091.07609.a0}

This information is current as of January 21, 2008

Updated Information \&

Services

References

Citations

Permissions \& Licensing

Reprints including high resolution figures, can be found at: http://n.neurology.org/content/70/4/322.full

This article cites 2 articles, 0 of which you can access for free at: http://n.neurology.org/content/70/4/322.full\#ref-list-1

This article has been cited by 1 HighWire-hosted articles: http://n.neurology.org/content/70/4/322.full\#\#otherarticles

Information about reproducing this article in parts (figures,tables) or in its entirety can be found online at:

http://www.neurology.org/about/about_the_journal\#permissions

Information about ordering reprints can be found online:

http://n.neurology.org/subscribers/advertise

Neurology ${ }^{\circledR}$ is the official journal of the American Academy of Neurology. Published continuously since 1951, it is now a weekly with 48 issues per year. Copyright. All rights reserved. Print ISSN: 0028-3878. Online ISSN: 1526-632X.

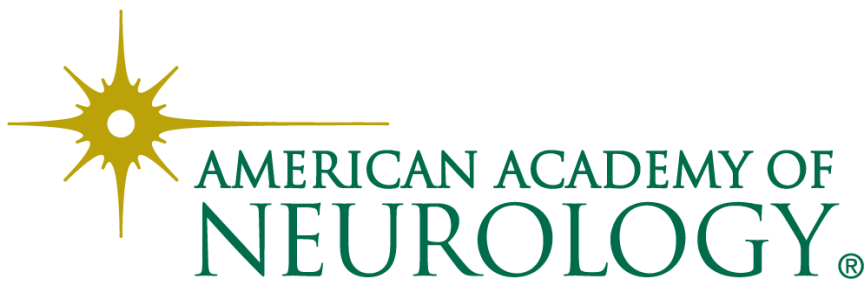

